Bulletin of the Zaporizhzhya National University. 2014. Vol. 4, Issue 1. P. 188-194.

4. Tiebout C. Economic Theory of Fiscak Decentralzation // Public Finances: Sources, and Utilization. Princeton, 1961. P. 79-96.

5. Bell M., Adams C. Fiscal Decentralization Indicators: Local Democratic Governance // Proceedings of 92' annual conference. Atlanta: National Tax Association, 1999. P. 236-241.

6. Bahl R. Implementation Rules for Fiscal Decentralization. Atlanta, 1999. URL: http://siteresources.worldbank.org/INTDSRE/Resources/3p.pdf

7. Reingewertz Y. Fiscal Decentralization - a Survey $f$ the Empirical Literature // MPRA Paper No. 9889. 2014. 46 p. doi: http:// doi.org/10.2139/ssrn.2523335

8. Rodriguez-Pose A., Ezcurra R. Is fiscal decentralization harmful for economic growth? Evidence from the OECD countries // Journal of Economic Geography. 2010. Vol. 11, Issue 4 P. 619-643. doi: http://doi.org/10.1093/jeg/lbq025

9. Vammalle C., Hulbert C. Sub-national Finances and Fiscal Consolidation: Walking on Th in Ice // OECD Regional Development Working Papers. 2013. doi: http://doi.org/10.1787/5k49m8cqkcf3-en
10. Sow M., Razafimahefa I. Fiscal Decentralization and the Efficiency of Public Service Delivery // IMF Working Papers New York: International Monetary Fund, 2015. Vol. 15, Issue 59. doi: http://doi.org/10.5089/9781484351116.001

11. Pedreja-Chaparro F., Salinas-Jimenez J., Suarez-Pandisllo J. Financing local governments: the Spanish experience // International Studies Program, Andrew Young School of Policy Studies, Georgia State University. 2006. Vol. 06-11. P. 11-12.

12. State Statistics Service of Ukraine. URL: http://www.ukrstat gov.ua/

Korytko Tetyana, PhD, Associate Professor, Department of Problems of Enterprise Economics, Institute of Industrial Economics of National Academy of Sciences of Ukraine, Kyiv, Ukraine, e-mail: Korytko@nas.gov.ua, ORCID: http://orcid.org/0000-0002-4251-1971

Kruk Olena, PhD, Associate Professor, Department of Finance, Banking and Entrepreneurship, Donbass State Engineering Academy, Kramatorsk, Ukraine, ORCID: http://orcid.org/0000-00025659-6603
Khalatur 5., Zubkova Yu.

\title{
IMPROVEMENT OF METHODOLOGICAL PRINCIPLES OF FINANCIAL RESOURCES MANAGEMENT OF ENTERPRISES IN ECONOMY OF UKRAINE
}

Об’єктом дослідження є фінансово-економічні відносини, що виникають в процесі управління фінансовими ресурсами підприємств в умовах нащіональної економіки України. Одним з найбільш проблемних місць є необхідність описати зв'язок між конкурентною стратегією підприємств на основі управління їх фінансовими ресурсами.

В процесі дослідження фінансових ресурсів як об’єкта фінансового менеджменту були використані методи індукиї і дедукиї, аналізу і синтезу. На основі методів інтерпретацї, системного і ретроспективного аналізу, спостереження, порівняння та графічного зображення результатів дослідження здійснювались оцінка динаміки та структури фінансових ресурсів підприємств України. При обгрунтуванні рекомендацій з удосконалення системи управління фінансовими ресурсами суб'єктів підприємництва національної економіки України були застосовані методи системності, комплексності, логічного моделювання.

Результати дослідження показали, що існують певні зв'язки при формуванні конкурентних стратегій підприємств на основі ефективності використання фінансових ресурсів. Підприємства національної економіки Украйни повинні формувати належні конкурентні стратегї, щоб покращити свої фінансові показники в мінливих економічних умовах. Слід знати та застосовувати відповідні стратегї, які стосуються ефективності використання фінансових ресурсів підприємств: корпоративний розвиток, функціональний рівень, ресурси та детермінанти вимірювання фінансової ефективності в різних економічних періодах. Ефективність управління фінансовими ресурсами підприємств начіональної економіки Украйни сприяє здатності до можливостей і стійкості до загроз, які існують в їх економічному середовищі, та забезпечить безперервний успіх підприємства.

Завдяки успішній реалізацї методологічних засад управління фінансовими ресурсами забезпечується можливість:

- відображати синтез інструментів зростання вартості підприємства (фінансового менеджменту);

- забезпечення потокового управління фінансовими ресурсами;

- формування чінності для всіх учасників ринку і суспільства (маркетингу);

- виявлення факторів та резервів створення цінності та вартості (фінансового аналізу);

- формування інформацї для емпіричного тестування моделей оцінювання (бухгалтерського обліку).

Ключові слова: конкурентні стратегї підприємств, ефективність управління фінансовими ресурсами, національна економіка України.

\section{Introduction}

Financial resources are assets of enterprises that influence the choice and possibilities of conducting financial and economic activities of business entities. Paradoxically, but in the flawless market, financial decisions of enterprises do not affect the corporate value, and financial resources are thus largely irrelevant. The possibility of increasing 
the economic output by eliminating the negative impact of financial resources and investments is an urgent problem.

The financial condition of most Ukrainian enterprises can be characterized as unsatisfactory. The problem for domestic business structures is the limited financial resources, which significantly affects the effectiveness of their management. Lack of financial resources prevents companies from investing in volumes that would meet the real needs of economic development. At the same time, insufficient provision of financial resources by enterprises is accompanied by low efficiency of their use. The current situation objectively requires new approaches to the formation and use of financial resources, the revitalization of the role of financial instruments in the management of financial resources of enterprises.

The efficiency of the functioning of enterprises, increasing their competitiveness, the pace of their development is largely determined by the level of financial resources management. Therefore, one of the most important directions of the financial policy of enterprises at the present stage is the formation of methodological principles for the management of financial resources, which should be aimed at ensuring profit growth, minimizing financial risks, providing the necessary liquidity. Therefore, research and solving of these issues are important as one of the important conditions for the activities of enterprises, achieving their sustainable and balanced development.

\section{The object of research and its technological audit}

The object of research is the financial and economic relations that arise in the process of managing financial resources of enterprises in the conditions of the national economy of Ukraine.

In order to effectively formulate and effectively use of financial resources of the enterprise, research is conducted on the directions of improvement of the methodological principles of management of financial resources. The most well-known experts [1-3] once again emphasized the methodology of innovative development of enterprise financing. That is why, developing theoretical, methodological and practical principles of financing and finding alternative sources of financing for innovative development of enterprises of the national economy of Ukraine, one should take an example of developed countries.

One of the most problematic places is the need to describe the relationship between the competitive strategies of enterprises based on managing their financial resources.

\section{The aim and objectives of research}

The aim of research is to substantiate the methodological principles of management of financial resources of enterprises in the Ukrainian economy.

To solve this aim the following tasks are formed:

1. To investigate the relationship between competitive strategies of enterprises and their financial resources.

2. To analyze the management of financial resources of enterprises in shaping strategies in different economic periods.

3. To substantiate the relationship between competitive strategies of the enterprise and their financial resources, financial productivity.

\section{Research of existing solutions of the problem}

Among the main directions of solving the problem of improving the methodological principles of management of financial resources of enterprises in the Ukrainian economy, identified in the resources of the world scientific periodicals, can be identified [4, 5]. But they do not consider the methodological recommendations on the directions of planning to ensure the formation of financial resources of the sub-objects of entrepreneurship.

And work [6] is devoted to the analysis of financial resources and their management, since they became very important, because enterprises cannot work without this kind of resources. Financial resources have become one of the important elements of the company's financial policy. Financial resources can come from internal and external sources. The internal sources of the enterprise are from undistributed profits and can receive external sources as loans and securities issue, but the issue of optimizing the structure of sources of financial resources of the enterprise is not resolved.

An alternative solution to the problem set forth in [1], which does not provide a system for managing financial resources of business entities, based on the use of formal plan documents - budgets.

Stock liquidity, corporate governance and leverage are shown in [2]. However, the described parameters do not have actual evidence in the development of economic and mathematical models for optimizing the structure of sources of financial resources of enterprises of the national economy.

In modern conditions strategic importance is acquired by strategic management at enterprises of various spheres of activity indicated in the paper [3]. This is aimed at consistently coordinating strategies and defining strategic benchmarks for all employees of the company. If there is a chain of supply then all its participants should be aimed at achieving common strategic goals through inter-organizational integration and coordination of efforts. This will give a synergistic effect that exceeds the sum of individual effects. However, this paper does not fully reveal the principles of strategically oriented management, which find its application both at the micro level and at the macro level.

The authors of the paper [7] show that access to finance is one of the key issues facing small business entities in the process of their creation, existence and development. The study of the current state of small business in Ukraine points to financial difficulties in the early stages of the life cycle, which determine the need to increase the importance of alternative sources of external financing and tools for the government and other stakeholders to understand the funding needs. The EU's experience demonstrates the need to support and develop informal investment at the stage of small business formation and development, and to evaluate government measures to increase the attractiveness of domestic small businesses. The study of the position of business angels in the financial support of small business has shown that they play a significant role in financing the stage of establishing a business in the EU, as well as traditional resources they have a number of advantages (ease of receipt, cost of attraction, additional consulting services, etc.). But the issue of Ukrainian 
practice of informal investments remains, which showed the poor development of angelic investment in Ukraine and the need to stimulate them through legal norms of legislation, competition policy regulation, entrepreneurial activity, cultural development, as well as the development of well-functioning financial markets.

According to the authors of the paper [8], public-private partnerships can become one of the main channels for expanding financial resources and attracting funds necessary for economic development. This does not confirm the possibility of the national economy of Ukraine, Taking into account the lack of public funds, lack of own funds to finance a capital-intensive public-private partnership. Consequently, the government should focus on incentives to stimulate bank lending as one of the key measures for PPP financial support by the public sector, including publicprivate lending through partnership agreements.

Considered in [9] systematic risk for the best investment decisions, which underlines the inaccuracy of determining the appointment of financial resources in the process of financing business.

The authors of the paper [10,11] emphasize the importance of evaluating systematic risk factors. Although this statement can be considered from the side of taking into account the features of management of financial resources of enterprises of the national economy of Ukraine.

Thus, the results of the analysis allow us to conclude that the improvement of the methodological principles of management of financial resources of enterprises in the national economy of Ukraine will allow us to ensure the rationality of the use of financial resources limited in the conditions of small business and increase the efficiency of their use.

\section{Methods of research}

In the study, the following scientific methods were used:

- methods of induction and deduction, analysis and synthesis were used in the process of studying financial resources as an object of financial management;

- on the basis of interpretation, system and retrospective analysis, observation, comparison and graphic representation of the results of the research, the estimation of dynamics and structure of financial resources of enterprises of Ukraine was carried out; - methods of systematic, complex, logical modeling were used to substantiate the recommendations for improving the financial resources management system of the subjects of entrepreneurship of the national economy of Ukraine.

\section{Research results}

Management of financial resources of enterprises is a multidimensional phenomenon, which is influenced by a large number of factors. Therefore, its successful implementation should reflect:

- synthesis of tools for increasing the cost of the enterprise (financial management);

- providing flow management financial resources;

- formation of value for all market participants and society (marketing);
- identifying factors and reserves for creating value and cost (financial analysis);

- formation of information for empirical testing of evaluation models (accounting).

Such circumstances require the formulation of appropriate methodological principles.

For a more detailed study of the topic in Fig. 1, let's consider the dynamics of financial results before taxation of enterprises of the national economy.

The development of the national economy of Ukraine is related to the financial condition of economic entities, which, in turn, depends on the efficiency of their activities. Profit is the main purpose of any enterprise activity, it is a criterion and an indicator of the effectiveness of such activity.

From the data shown in Fig. 1, it is evident that in 2017 against 2009, corporate profits grew to $287848.5 \mathrm{mil}-$ lion UAH against (-45011.3 million UAH) in 2009. The branch of agriculture during the investigated period was profitable, the positive financial result ranged from 7647.4 million UAH in 2009 to 91109.5 million UAH in 2016. Industry, building and trade were unprofitable for 2014-2015. In 2017, the studied sectors of the national economy of Ukraine received a positive financial result. That is, we see a positive tendency to increase the profits of enterprises, with the increase in the number of lossmaking enterprises. The main factors in improving the financial performance of the country's enterprises are the emergence of an economic crisis and the improvement of the global economic development trend.

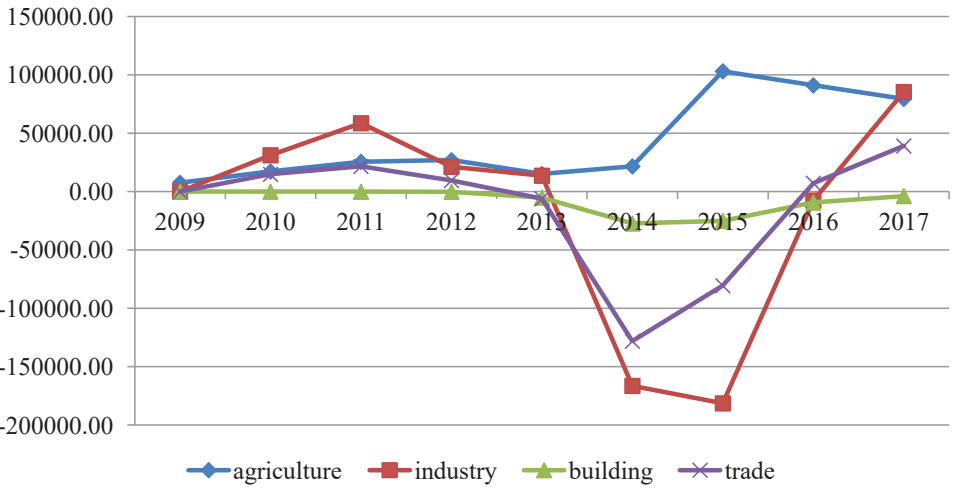

ig. 1. Dynamics of financial results before taxation of enterprises of the national economy (calculated according to the data of State Statistics Committee of Ukraine)

In Fig. 2, it is possible to consider the dynamics of enterprises of the national economy, which have received profit, in $\%$ to the total number of enterprises.

Analysis of Fig. 2 shows that the largest number of profitable enterprises among the surveyed sectors in rural households (from $69.7 \%$ in 2009 to $86.2 \%$ in 2017 from the total number of enterprises). In industry, in 2009, $59.5 \%$ of profitable enterprises and $71.6 \%$ in 2017 . The buiding sector and the trade sector show a similar dynamics of the number of profitable enterprises as a percentage of the total number of enterprises. In general, in the national economy of Ukraine there is a positive tendency to increase the number of profitable enterprises in 2017 compared to 2009.

Fig. 3 shows the dynamics of enterprises of the national economy with different performance of activity. 


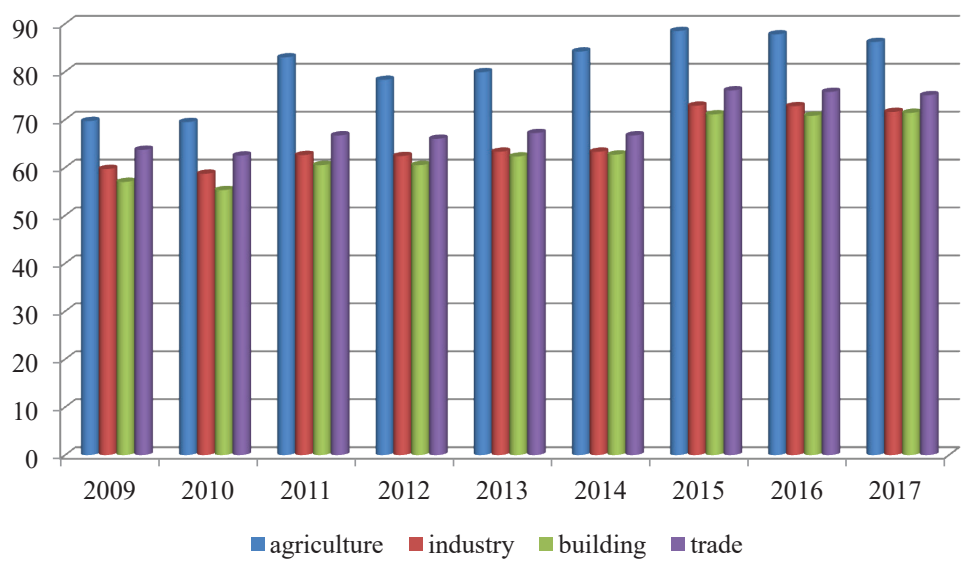

Fig. 2. Dynamics of enterprises of the national economy, which received profit, in \% to the total number of enterprises (calculated according to the data of State Statistics Committee of Ukraine)

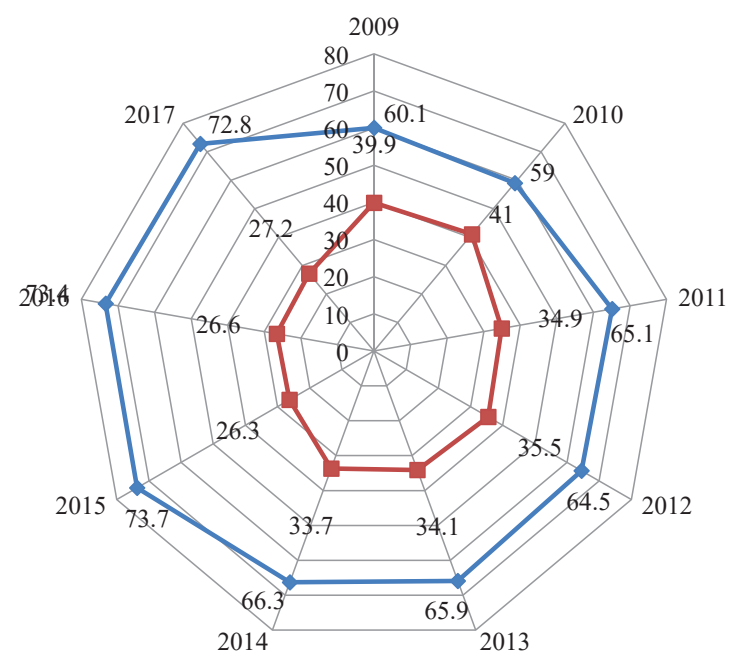

$\multimap$ Enterprises that have earned profit, $\%$ of the total number of enterprises

-Enterprises that have losses, $\%$ of the total number of enterprises

Fig. 3. Dynamics of enterprises of national economy with different efficiency of activity (calculated according to the data of State Statistics Committee of Ukraine) should effectively choose the appropriate development strategy so that it is flexible and can be adjusted according to market conditions as necessary.

Profit can be determined by internal factors (using different development strategies) and external factors (economic conditions). The enterprise strategies that were agreed upon at the corporate, business and functional levels include the type of activity, geographical distribution, cost control and productivity of financial resources. Thus, profit before tax is considered the most important indicator of measuring the efficiency of using financial resources of the enterprise, and then - the movement of funds. Indicators of the efficiency of using financial resources of the enterprise will be more influenced by the general state of the economy of the country, rather than their own operating strategies.

In Fig. 4 it is analyzed the development strategies of the enterprise in view of the alternatives to the use of financial resources.

In Fig. 5 it is schematically shown the strategic directions of enterprise development in the national economy of Ukraine.

Fig. 5 defines the strategic directions that the company can take. The form of the framework adopts a set of products or market choices summed up in Fig. 5. However, it should be recognized that this is, in essence, the environmental outlook: it assumes that there are environmental opportunities for growth, the benefits of which can be exploited by enterprises. While this may be possible for many businesses, others will not be able to take advantage of such circumstances. For example, enterprises in a stable environment or in declining market situations may be primarily related to the development of a specific core competence of a specialist, or with the development of more efficient use of resources, or even with the prospect of foreclosure planning. There are a number of directions that an enterprise can follow to evolve in a different environment, including output, consolidation, product development, market development and diversification.

Enterprises are developing in different economic conditions; the environment has a significant impact on the financial performance of the financial resources of companies in the long run. An enterprise has the ability to choose the type of activity that corresponds to its goals and available financial resources. Then it can be diversified into other types of activities or remain with existing business activity depending on the efficiency of using the company's financial resources. An enterprise can concentrate on the Ukrainian market or go with its products outside the country or to other continents. Regardless of the decisions made, they can't be easily changed without adapting to the economic environment.

For example, an enterprise that is already diversified cannot be easily managed by any of its activities to refocus on its financial resources. This will affect employees, the structure of the enterprise and may be ineffective in terms of using financial resources. Therefore, an enterprise

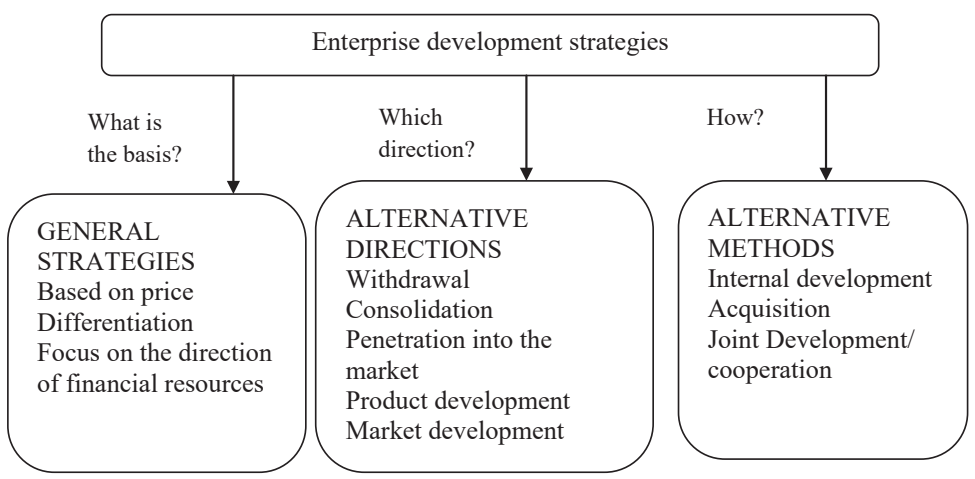

Fig. 4. Strategies for enterprise development in view of alternatives to the use of financial resources

Support for a stable level of competitive advantage of enterprises of the national economy on the basis of effective use of financial resources involves taking into account external and internal factors, flexibility of functioning, strategic potential. The external flexibility of an 
individual enterprise is associated with a change in the sets of strategic areas of management, with the need for continuous management of these sets. Internal flexibility of an enterprise is connected with the change of sets of strategic goals.

\section{Related development \\ 2. Related diversification \\ 3. Unrelated diversification}

Product

\begin{tabular}{c|l|l|}
\multicolumn{1}{c}{ Present } & \multicolumn{1}{c|}{ New } \\
\cline { 2 - 3 } Present & $\begin{array}{l}\text { Withdrawal } \\
\text { Consolidation } \\
\text { Penetration into the } \\
\text { market }\end{array}$ & $\begin{array}{l}\text { Product } \\
\text { development }\end{array}$ \\
\cline { 2 - 3 } New & $\begin{array}{l}\text { Market } \\
\text { development }\end{array}$ & $\begin{array}{l}\text { Diversification } \\
(2 \text { and 3) }\end{array}$ \\
\hline
\end{tabular}

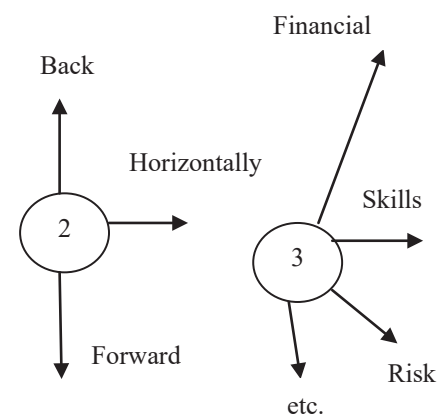

Fig. 5. Strategic directions of development of enterprises in the national economy of Ukraine
- accountability - collecting and reporting on the progress of the strategy implementation, including reports on accomplished tasks in accordance with the expected goal and forecasting based on available results; - control over changing the content of the strategy; - control over changes in the schedule of measures of the strategy;

- control over transactions and changes to the budget strategy;

- quality control - evaluating the specific results of the strategy implementation in order to determine their compliance with the standards and taking the necessary measures to eliminate the causes that lead to quality impairment;

In order to achieve internal flexibility, an enterprise must be equipped with easily adjustable means of technological equipment; have the specialists who are able to quickly and efficiently develop new products. Enterprises of the branches of the national economy should promptly analyze and use the full amount of up-to-date information on the state and possible changes in the situation in the macro and micro environment.

The data necessary for monitoring the implementation of the strategy of economic development of the enterprise on the basis of the effective use of financial resources is given in Table 1.

Table 1

Criteria for monitoring the implementation of the strategy of economic development of the enterprise based on the effective use of financial resources

\begin{tabular}{|l|l|l|}
\hline Criteria for control & \multicolumn{1}{|c|}{ Duantitative data } & Qualitative data \\
\hline Time and cost & $\begin{array}{l}\text { Scheduled start/end time. } \\
\text { Actual start/end time. } \\
\text { Number of events. } \\
\text { The number of planned activities. } \\
\text { Other actual expenses }\end{array}$ & - \\
\hline Quality & - & Quality issues \\
\hline Organization & - & External delays \\
\hline $\begin{array}{l}\text { Activities on the } \\
\text { implementation of } \\
\text { changes }\end{array}$ & - & $\begin{array}{l}\text { Problems of } \\
\text { resource coordi- } \\
\text { nation }\end{array}$ \\
\hline
\end{tabular}

Based on the criteria for monitoring the implementation of the economic development strategy of the enterprise on the basis of the effective use of resources (Table 1), let's select the basic methods of analysis used to monitor the implementation of the strategy, include the gathering of evidence and the assessment of actual costs, the amount of work remaining, the actual implementation of all stages of the strategy for a certain time. The process of implementation of the implementation strategy is divided into the following stages:

- general control of changes - coordination of changes in the program as a whole;
- risk control - response to changes in the level of risk in the implementation of the strategy.

The overall monitoring of the economic development strategy is implemented in order to assess the factors that lead to positive or negative changes; identify changes that have already been made and effectively manage changes in strategy implementation. strategy of economic development, the following methods can be used:

- simple control, also called the $\ll 0-100 »$ method, because it monitors only the stages of specific activities (there are two stages of the completion strategy: $0 \%$ and $100 \%$ ). In other words, this strategy is considered effective only if the desired result is achieved;

- detailed monitoring, which provides an assessment of the intermediate stages of the strategy implementation. This method is more complex because it requires an estimate of the percentage of implementation of specific measures and projects. summarized for upper levels of control according to the strategy of activity. Monitoring the implementation of the strategy of economic development includes the accounting changes that may occur during the implementation of the strategy. Changing management is a process of forecasting and planning future changes, recording all potential changes for detailed study, impact assessment, approval or rejection and correction.

The change involves the replacement of one solution by others as a result of the influence of various external and internal factors in the design and implementation of a strategy of activity. In some cases, changes can be caused by the inability to find any working options at the stage of strategy development, as well as delayed schedules and workload due to unforeseen circumstances.

To monitor the implementation of the strategy of economic development, there are many formal procedures that determine the changes in the legal acts adopted earlier and official approval documents (Fig. 6).

This is necessary for the successful formation and implementation of the strategy of economic development of enterprises based on the effective use of financial resources.
During the monitoring of the implementation of the

Quantitative indicators derived from work are then 


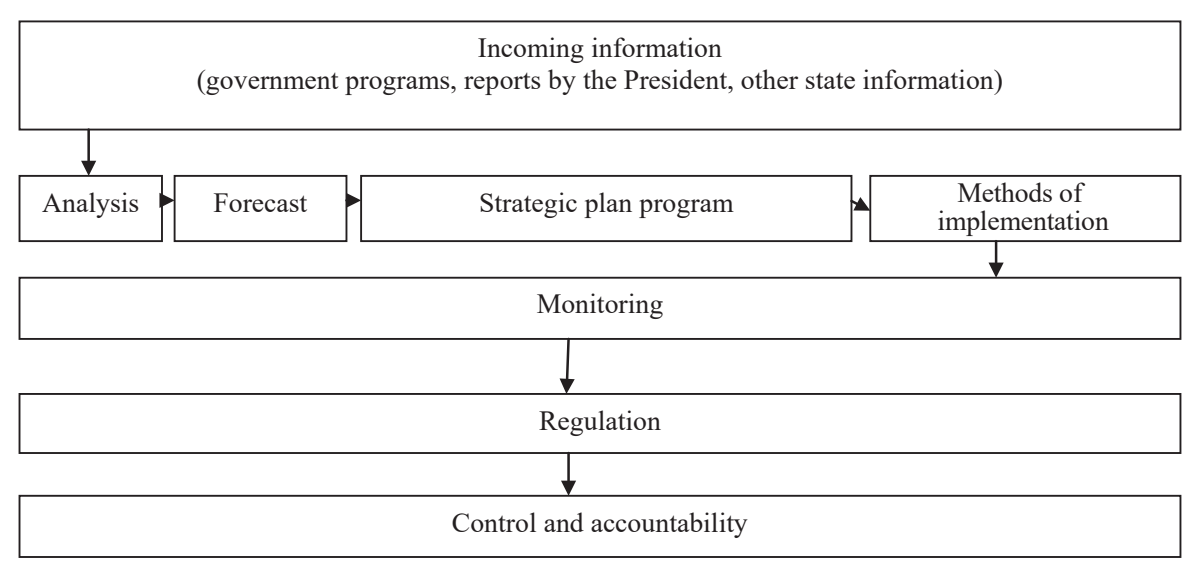

Fig. 6. Place of monitoring in the process of planning the strategy of economic development of enterprises based on the effective use of financial resources

Workflow systems make it possible to analyze changes in procedures in some situations that can be taken without consideration, can be used (for example, when making a decision or in emergencies). Changes must be documented and adopted in order to avoid further problems caused by the lack of information about the actual situation in the strategy. The results of the overall monitoring of the implementation of the strategy include a fundamental strategy plan, approved changes necessarily brought to the notice of the performers.

The development and use of the monitoring system for implementing the agricultural development strategy provides for:

- a list of controlled parameters and their standard values;

- responsible persons;

- the order of using the results of monitoring the implementation of the strategy.

When developing a list of indicators and their limitations, one should consider:

- availability of state and departmental statistics;

- availability of resources for monitoring;

- criterion of relevance of the system of indicators.

An adequately constructed system for monitoring the implementation of a strategy for economic development allows:

- receive the necessary information on the progress

of the strategy implementation;

- respond timely to deviations of controlled parameters;

- optimize information flows while implementing the strategy.

The monitoring function of the strategy also solves the problems of predicting and assessing the operational situation on a specific date in order to determine the results, costs, time, resources and finances, analyze and eliminate the reasons for the deviation from the preapproved strategy. When determining the effectiveness of implementing a strategy, you must adhere to the following principles:

1) the best choice on the basis of comparison;

2) comprehensive assessment of strategy options in terms of economic, social and environmental impacts;

3) factors of uncertainty (risk);

4) possible number of alternative strategy measures.

The proposed systematic methodological approach to developing a strategy for economic development of en- terprises based on the effective use of financial resources includes:

- a state approach to the development of strategies for the development of enterprises of the national economy of Ukraine;

- systematic analysis of the state and trends of production supply in the state;

- sufficiency, efficiency and harmonization of legislative and normative support;

- ecological and economic features of the functioning of the branches of the national economy.

Also, the systematic methodological approach to developing a strategy for the economic development of enterprises based on the effective use of financial resources includes prospects for the development of the industry; scientific and technical support for the functioning and rational use of natural resources in the context of global natural and economic processes.

The functioning of a separate branch of the national economy as a system is ensured by a rational organization, certain organizational relations, active actions on the part of economic actors, which are important factors of the industry's development.

In Fig. 7 the proposed model of the process of ensuring sustainable economic development of enterprises on the basis of the effective use of financial resources. Author's approach to the formation of a strategy of economic development of enterprises on the basis of the effective use of financial resources as market participants provides for the following rules and techniques:

- study of the conditions of competitive advantage formed by the determinants of «national diamond» inside and outside the country and the identification of a better mission;

- research potential markets for goods and services that meet the mission of businesses and industry in general, and the selection of strategic areas of management, which are capable of in the long run to provide the flexibility enterprises and organizations, i. e. the possibility to reorient their functioning in the most economically favorable, political, legal, sociocultural, scientific-technical and environmental points of view;

- the formation of trade flows industries that best meet the most urgent needs individually and production potential buyers at home and abroad and 
on that basis the stable functioning of all businesses;

- distribution of available resources at the disposal of the economy among commodity producers, which ensure the solution of the tasks of maximizing the profitability of using own and borrowed funds;

- interaction of enterprises with the markets of means of production, securities, foreign exchange markets, which provide economically effective support of the strategic potential of the industry;

- the formation of an effective pricing policy in the country, which in the long run provides a sustainable position for agricultural organizations in the regional and national agrarian markets;

- timely detection of crisis trends within the regional and national economy and its branches and prevention of bankruptcy of enterprises.
In developing rules and techniques for the effective implementation of these activities, the strategy of economic development of enterprises on the basis of the effective use of financial resources should be aimed at supporting the competitive advantage of economic actors in the industry, to help prevent bankruptcy and ensure their sustainable development.

The strategy of economic development of enterprises on the basis of the effective use of financial resources should be based on the following areas:

- collection and processing of significant volumes of different types of information;

- conducting negotiations with numerous groups of strategic influence, potential resource providers, customers, customers and other contact audiences;

- monitoring of markets for food and non-food products from agricultural raw materials and services.

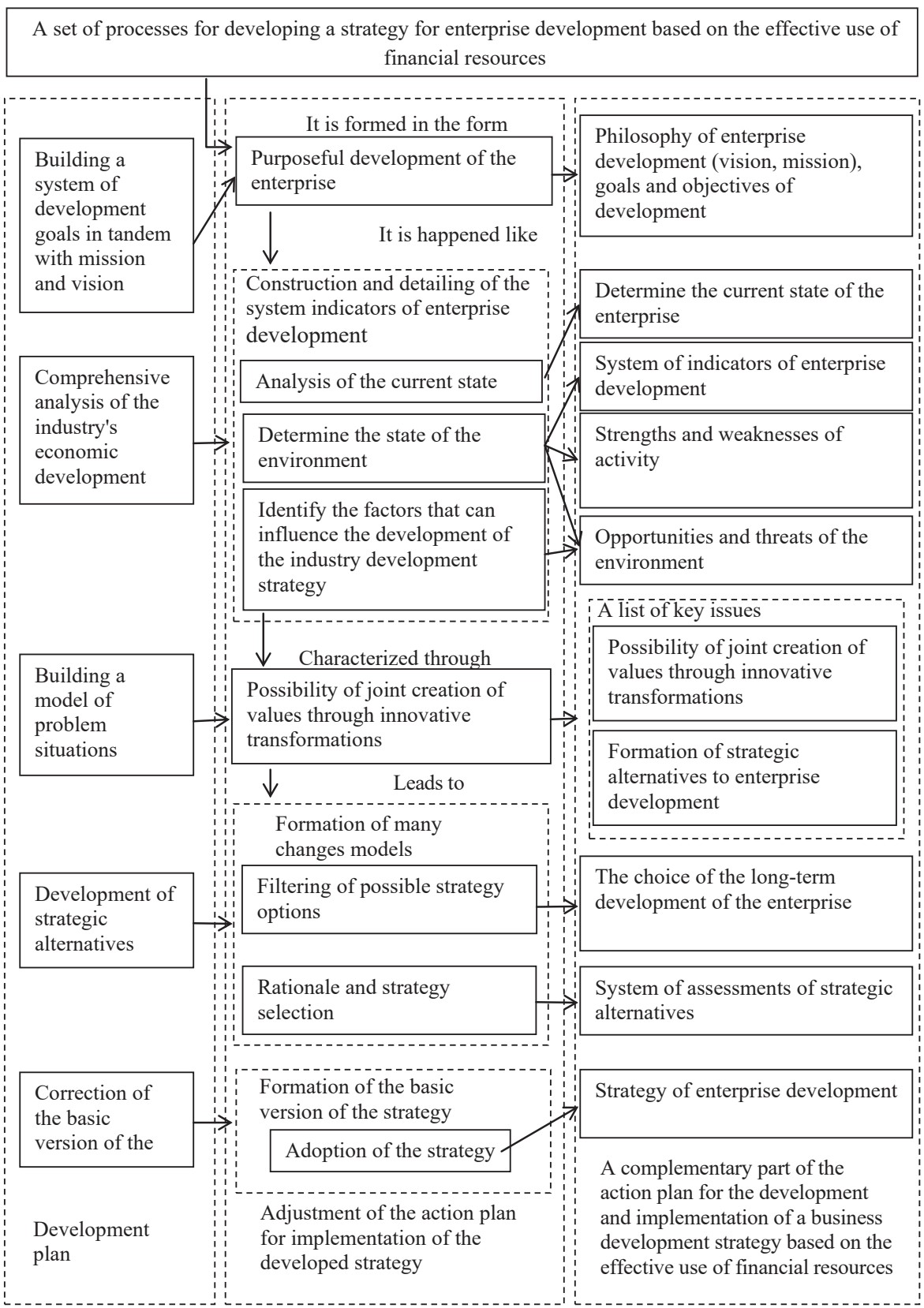

Fig. 7. System model of the process of developing and adopting a strategy for economic development of enterprises based on the effective use of financial resources 
The development of options and the choice of a better strategy for economic development, we understand, as a process of forming a set of strategic diverse agreements with partners, which business entities in the industry should implement in the long run.

The success of the implementation of enterprises in their production mission in the long run is determined by the degree of achievement of the global strategic goal.

\section{SWOT analysis of research results}

Strengths. The positive effect of research is improvement and formulation of practical tools for managing financial resources of enterprises.

Weaknesses. The weakness of this research in this direction consists in the absence of an economic and mathematical model for optimizing the structure of sources of financial resources of business entities, which provides justification for the feasibility of using different sources of formation of financial resources of the enterprise, their volume, composition and structures, taking into account expected future cash flows and needs in financing and allows to find quantitative expressions of interconnections between financial indicators and factors that determine them.

Opportunities. The prospect of further research in this direction is creation of econometric and optimization models, the introduction of which will allow the establishment of scientific and substantiated ways to increase the efficiency of the formation and use of financial resources of enterprises in the national economy of Ukraine.

Threats. The research results indicate that the change in economic relations and production conditions requires clarification of the methodology for determining the efficiency of management of financial resources of enterprises. Insignificant volumes of profit and amortization deductions do not allow some enterprises to conduct an active investment policy, do not create the appropriate financial conditions of economic development of enterprises, cause the need for significant mobilization of financial resources at the expense of external sources of financing in order to ensure the economic development of enterprises.

\section{Conclusions}

1. The relations between competitive strategies of enterprises and their financial resources were investigated. Selected four strategic variables representing competitive strategies:

- type of activity;

- diversification;

- internationalization degree;

- level of funding.

The financial performance of the company was represented by five variables:

- profitability of used working capital;

- turnover of funds; current liquidity ratio;

- quick liquidity ratio;

- commodity turnover.

2. Financial resources of enterprises in the formation of strategies were investigated in different economic periods.
The following key variables were chosen to represent the financing of enterprise strategies:

- direction;

- method;

- diversification;

- internationalization;

- functionality;

- resource:

- financial performance;

- the determinants of financial activity.

3. The findings have shown that there is a significant relationship between the competitive strategies of the enterprise and their financial resources, financial performance, which in turn depends on the type of activity, profitability and liquidity. Profitability is also affected by the level of turnover of resources. However, the diversification degree and the scale of internationalization have a strong impact on the turnover of resources. Advanced technologies are not considered important functional elements of the strategy. Management, skilled workers and capital are the three most critical resources. The cash flow is considered to be the most important financial indicator of financial resource productivity, while the state of the market is perceived as the most important factor in the formation of financial resources.

\section{References}

1. The new decomposition asset growth effect. An empirical evidence of Indonesia / Laksana R. D. et. al. // Journal of Applied Economic Sciences. 2017. Vol. 12, Issue 4 (50). P. 977-984. URL: http://cesmaa.org/Docs/JAES \%20Summer \%20XII $\% 204(50) 2017$ online.pdf

2. Stock liquidity, corporate governance and leverage: New pane evidence / Nadarajah S. et. al. // Pacific-Basin Finance Journal. 2018. Vol. 50. P. 216-234. doi: https://doi.org/10.1016/ j.pacfin.2016.11.004

3. Strategically supplier-oriented management in the procurement process of JSC «Russian Railways» / Karpova N. et. al. // Problems and Perspectives in Management. 2018. Vol. 16, Issue 3. P. 14-27. doi: https://doi.org/10.21511/ppm.16(3).2018.02

4. Matveieva N. V. Pervukhin P. K. Napriamy pidvyshchennia efektyvnosti vykorystannia finansovykh resursiv pidpryiemstv // Nauka y ekonomika. 2016. Issue 2. P. 17-21.

5. Khasawneh A. Y., Dasouqi Q. A. Sales nationality and debt financing impact on firm's performance and risk // EuroMed Journal of Business. 2017. Vol. 12, Issue 1. P. 103-126. doi: https:// doi.org/10.1108/emjb-05-2016-0015

6. Shaferi I., Dhani Laksana R., Wahyudi S. The effect of risk leverage on investors' preferences in manufacturing companies listed on the Indonesia Stock Exchange // Investment Management and Financial Innovations. 2018. Vol. 15, Issue 3. P. 190-198. doi: https://doi.org/10.21511/imfi.15(3).2018.16

7. Business angels as an alternative to financial support at the early stages of small businesses' life cycle / Pedchenko N. et. al. // Investment Management and Financial Innovations. 2018. Vol. 15, Issue 1. P. 166-179. doi: https://doi.org/10.21511/ imfi.15(1).2018.15

8. Kolodiziev O., Tyschenko V., Azizova K. Project finance risk management for public-private partnership // Investment Management and Financial Innovations. 2017. Vol. 14, Issue 4. P. 171-180. doi: https://doi.org/10.21511/imfi.14(4).2017.14

9. Puspitaningtyas Z. Estimating systematic risk for the best investment decisions on manufacturing company in Indonesia // Investment Management and Financial Innovations. 2017. Vol. 14, Issue 1. P. 46-54. doi: https://doi.org/10.21511/ imfi.14(1).2017.05 
10. Lang S., Scholz A. The diverging role of the systematic risk factors: evidence from real estate stock markets // Journal of Property Investment \& Finance. 2015. Vol. 33, Issue 1. P. 81-106. doi: https://doi.org/10.1108/jpif-05-2014-0032

11. Organizational and financial mechanisms for implementation of the projects in the field of increasing the energy efficiency of the regional economy / Tsurkan M. et. al. // Problems and Perspectives in Management. 2017. Vol. 15, Issue 3. P. 453-466. doi: https://doi.org/10.21511/ppm.15(3-2).2017.13
Khalatur Svetlana, Doctor of Economic Sciences, Associate Professor, Department of Finance, Banking and Insurance, Dnipro State Agrarian and Economic University,Ukraine, e-mail: halatyr@i.ua, ORCID: http://orcid.org/0000-0001-8331-3341

Zubkova Yuliia, Department of Finance, Banking and Insurance, Dnipro State Agrarian and Economic University, Ukraine, e-mail: yulyazubkova261@gmail.com, ORCID: http://orcid.org/0000-00020038-0563

UDC 339.13 .012

JEL Classification: F65

DOI: 10.15587/2312-8372.2018.146142

\section{Bondarenko M. ANALYSIS OF THE REGIONAL Bunin 5. DIFFERENTIATION OF THE WORLD FINANCIAI MARKET}

Об'єктом дослідження є світовий фінансовий ринок, який об'єднує національні фінансові системи та має значну регіональну диференціацію розвитку. Одним з найбільш проблемних місць розвитку світового фінансового ринку є зниження внутрішньо-регуляторного впливу країн на свою фінансову систему. А також зростання світової заборгованості країн за зовнішніми запозиченнями, непостійний характер розвитку ринку, де проявляє свою дію закон нерівномірності економічного розвитку.

В ході дослідження використовувався аналіз динаміки розвитку світового фінансового ринку за такими показниками, як:

- прямі іноземні інвестиції та їх чистий відтік (\% від ВВП);

- прямі іноземні інвестиції та їх чистий приток (\% від ВВП);

- кількість національних компаній, що котируються на біржі та їх ринкова капіталізація.

За допомогою класичних загальнонаукових методів дослідження, регресійного аналізу, методів статистичної обробки даних отримано, що найменші показники відтоку капіталу притаманні країнам стрімкого характеру розвитку (регіон Латинської Америки та Карибського басейну, Південної Азії). Найбільші показники притоку капіталу притаманні високорозвиненим крайнам, що входять до Європейського Союзу або Сврозони. Більшість компаній, що мають котирування на біржі та найбільшу ринкову капіталізацію, розташована в країнах ОЕСР (Організація економічного співробітництва та розвитку), у тому числі в країнах Європейсъкого Союзу. Це пов'язано з тим, що всі складові фінансового ринку перебувають у тісному взаємозв'язку. Збільшення обсягів грошових заощаджень населення і вільних коштів підприємств сприяє розширенню та активізацї кредитного ринку і ринку цінних паперів. А випуск цінних паперів знижує потребу у фінансуванні економіки за рахунок кредитів та акумулює тимчасово вільні грошові кошти інвесторів. Завдяки цвому забезпечується умовний характер поділу фінансових ринків на ринок грошей і ринок капіталів.

Ключові слова: світовий фінансовий ринок, регіональна диференціація розвитку, прямі іноземні інвестиції, фінансова капіталізація нащіональних компаній.

\section{Introduction}

In the modern world, the processes of financial globalization are unfolding and the dependence of individual countries on world financial markets is increasing. This trend is typical for many countries of the world and requires coordinated actions from financial market regulators in order to ensure sustainable and dynamic development of the financial sector. The objective basis for the development of the world market is the development of the international division of labor; internationalization of social production; concentration and centralization of financial capital. The modern world financial market unites the na- tional financial markets of countries and the international financial market, they differ in terms of the issue and the mechanism of circulation of financial assets. Considering this, the study of imbalances in the development of the world market and the study of its regional differences at the present stage is highly relevant.

\section{The object of research and its technological audit}

The object of research is the global financial market, which unites national financial systems and has significant regional development differentiation. In particular, the 